\title{
Peran Lem Fibrin Otologus pada Penempelan Tandur Konjungtiva Bulbi Mata Kelinci terhadap Ekspresi Gen Fibronektin dan Integrin
}

\author{
Sutarya Enus, ${ }^{1}$ Gantira Natadisastra, ${ }^{1}$ M. Nurhalim Shahib, ${ }^{2}$ Rachmat Sulaeman ${ }^{3}$ \\ ${ }^{1}$ Departemen Ilmu Kesehatan Mata Fakultas Kedokteran Universitas Padjadjaran-Rumah Sakit \\ Cicendo Bandung; ${ }^{2}$ Departemen Bio Kimia, ${ }^{3}$ Departemen Ilmu Penyakit Dalam \\ Fakultas Kedokteran Universitas Padjadjaran-Rumah Sakit Dr. Hasan Sadikin Bandung
}

\begin{abstract}
Abstrak
Penempelan jaringan dan penyembuhan luka pada cangkok konjungtiva lebih cepat pada teknik lem fibrin otologus (LFO) dibandingkan dengan teknik jahitan. Kedua proses tersebut memerlukan interaksi fibronektin (FN) dan integrin $\alpha_{5}$ yang mengaktivasi alur persinyalan intraselular. Tujuan penelitian untuk menentukan kekuatan ekspresi gen FN serta integrin $\alpha_{5}$ pada kelompok teknik LFO dan jahitan. Uji eksperimental hewan pada kelinci New Zealand White yang terbagi kelompok teknik LFO dan jahitan masing-masing 8 kelinci bertempat di Laboratorium Sentral (Biologi Molekuler) FK Unpad Bandung, periode Mei-Oktober 2008. Sampel jaringan untuk pemeriksaan reverse transcriptase polymerase chain reaction (RT-PCR) diambil dari eksterpasi satu hari sesudah jaringan cangkok konjungtiva bulbi. Analisis data untuk uji hipotesis dengan Mann Whitney for small sample. Ekspresi gen messenger ribonucleic acid (mRNA) FN secara bermakna lebih kuat pada teknik LFO dibandingkan dengan teknik jahitan $(1,9$ vs 1,$0 ; p=0,014)$. Tidak terdapat perbedaan bermakna ekspresi gen (mRNA) integrin $\alpha_{5}$ antara teknik LFO dan teknik jahitan $(1,2$ vs 1,$0 ; p=0,235)$. Sebagai simpulan ekspresi gen FN lebih kuat pada teknik LFO dibandingkan dengan jahitan, sedangkan ekspresi gen integrin $\alpha_{5}$ pada teknik LFO lebih kuat dibandingkan dengan teknik jahitan namun secara statistik tidak bermakna satu hari pascabedah. [MKB. 2011;43(4):183-8].
\end{abstract}

Kata kunci: Fibronektin, integrin $\alpha_{5}$, lem fibrin otologus, RT-PCR

\section{The Role of Autologous Fibrin Glue on Attachment Rabbit Conjungtival Graft Based on Fibronectin and Integrin Gene Expression}

\begin{abstract}
The tissue attachment and wound healing in conjunctional transplantation was more rapid with autologous fibrin glue (AFG) than suture techniques. Both tissue attachment and wound healing process need interaction between fibronectin (FN) dan integrin $\alpha_{5}$ activating the intra cellular signal transduction pathway. The aim of this study was to evaluate the gene expression, i.e. FN and integrin in conjunctival transplantation, comparing between AFG and suturing techniques. Animal experimental study was done in New Zealand White rabbits, which divided into AFG and suturing technique at Laboratorium Sentral (Biologi Molekuler) FK Unpad Bandung during May-October 2008, each 8 rabbits, respectively. The tissue sample for reverse transcriptase polymerase chain reaction (RT-PCR) examination was taken from the tissue excision one day after conjunctival bulbi transplantation. Data analysis was tested using Mann Whitney for small sample. The FN gene expression power of messenger ribonucleic acid (mRNA) in the AFG technique was stronger than that in suturing technique $(1.9$ vs $1.0, p=0.014)$. There was no significant difference in integrin $\alpha_{5}$ gene expression of mRNA between AFG and suturing techniques (1.2 vs 1.0 , $\mathrm{p}=0.235)$. In conclusions, FN gene expression in AFG technique is stronger than suturing technique. There is no difference in integrin $\alpha_{5}$ gene expression between two techniques, however there is a tendency of increased integrin $\alpha_{5}$ gene expression one day after surgery. [MKB. 2011;43(4):183-8].
\end{abstract}

Key words: Autologous fibrin glue, fibronectin, integrin $\alpha_{5}$, RT-PCR

Korespondensi: Dr. Sutarya Enus, dr, SpM(K), M.Kes, Departemen Ilmu Kesehatan Mata, Fakultas Kedokteran Universitas Padjadjaran-Rumah Sakit Mata Cicendo, jalan Cicendo No. 4 Bandung, telepon (022) 4210883, mobile 08122353663, e-mail sutaryaenus@yahoo.com 


\section{Pendahuluan}

Pembedahan pterigium disertai transplantasi jaringan cangkok (tandur) konjungtiva merupakan standar terapi dan telah teruji dapat menurunkan angka tumbuh ulang dibandingkan dengan tanpa cangkok konjungtiva. ${ }^{1}$ Metode untuk penempelan cangkok konjungtiva menggunakan jahitan merupakan bedah mikro yang rumit, waktu penyembuhan luka berlangsung lama, dan kemungkinan timbul komplikasi akibat jahitan berupa infeksi, granuloma, serta kematian jaringan cangkok. ${ }^{1,2}$

Lem biologis, seperti lem fibrin komersial (LFK) terdiri atas 2 komponen, yaitu fibrinogen terbuat dari plasma beku donor (homologus) dan trombin terbuat dari plasma beku segar bovine. Lem fibronektin komersial sebagai pengganti jahitan banyak memberikan keuntungan, antara lain waktu operasi lebih singkat, serta mempercepat penempelan jaringan dan penyembuhan luka. ${ }^{3}$ Sampai saat ini LFK belum tersedia di Indonesia karena harus diimpor dengan harga yang mahal dan perlu penyimpanan khusus. Food and Drug Administration (FDA) belum secara resmi mengeluarkan izin untuk pemakaian LFK pada operasi mata karena terbuat dari protein asing yang dikhawatirkan akan menularkan penyakit. ${ }^{4}$

Akhir-akhir ini di Indonesia terjadi peningkatan transplantasi (tandur) konjungtiva bulbi yang pesat untuk menurunkan angka tumbuh ulang pterigium. ${ }^{5}$ Situasi tersebut di atas menggugah peneliti untuk membuat suatu terobosan teknik tepat guna untuk kondisi Indonesia dengan membuat lem fibrin otologus (LFO) yang dibuat langsung dari darah penderita sebagai pengganti jahitan dan pembuatan LFO dapat dilakukan oleh tenaga analis. Karena LFO berasal dari darah penderita sendiri, maka akan terhindar dari transmisi penyakit, reaksi alergi, serta murah dan mudah didapat.

Telah kami lakukan uji eksperimental hewan di Laboratorium Bio Farma pada tahun 20062007 dengan hasil teknik LFO lebih efektif dibandingkan dengan teknik jahitan, karena ditinjau dari lamanya operasi lebih singkat, serta penempelan jaringan dan penyembuhan luka lebih cepat. ${ }^{6}$

Teknik jahitan pada tandur konjungtiva bulbi merupakan trauma tambahan yang dapat menimbulkan reaksi inflamasi berlebih, serta memperlambat adhesi jaringan dan penyembuhan luka. ${ }^{7}$ Lem fibrin akan meningkatkan fibronektin yang merupakan ligan terutama untuk reseptor integrin $\alpha_{5} \beta_{1}$. Proses adhesi ini akan mengubah sinyal intraselular, meregulasi faktor transkripsi, dan mengaktivasi gen yang terkait dengan fungsi spesifik. $^{8}$

Peningkatan protein adhesi fibronektin dan integrin yang disebabkan aktivasi ekspresi gen dapat dideteksi secara dini dengan peningkatan ekspresi messenger ribonucleic acid (mRNA) sebagai prekursor kedua protein tersebut. ${ }^{9}$

Penggunaan jahitan pada tandur konjungtiva bulbi untuk eksisi bedah pterigium sampai saat ini masih merupakan standar baku dan akan digunakan sebagai kelompok kontrol untuk meneliti respons selular.

Tujuan penelitian ini untuk menentukan kekuatan ekspresi gen (mRNA) fibronectin (FN) serta integrin $\alpha_{5}$ pada teknik LFO dan teknik jahitan. Dengan mengetahui mekanisme kerja LFO pada tingkat biologi molekular akan merupakan dasar ilmiah untuk uji klinik penggunaan LFO pada transplantasi konjungtiva penderita pterigium.

\section{Metode}

Penelitian berupa animal experimental study, desain paralel dengan metode tersamar ganda untuk membandingkan ekspresi gen (mRNA) FN dengan integrin. Subjek penelitian berdasarkan ketentuan Association for Research in Vision and Ophthalmology (ARVO) ${ }^{10}$ yaitu kelinci New Zealand White biakan Bio Farma masing-masing kelompok 8 ekor, umur 2-3 bulan, bobot 2-2,5 kg, sehat, dan tidak cacat. Kelinci dikarantina selama $1-4$ minggu.

Skala pengukuran untuk menilai kekuatan ekspresi gen secara semikuantitatif (ordinal) dengan urutan nilai gradasi berturut-turut 1 (tidak terekspresi), 2 (terekspresi lemah), 3 (terekspresi sedang), dan 4 (terekspresi kuat). Nilai 1 sesuai dengan kontrol negatif, nilai 4 sesuai dengan kontrol positif, yaitu kombinasi ketegasan batas kepadatan konsistensi dan kejelasan kontras pada ekspresi gen jelas terlihat, sedangkan nilai 2 dan 3 di antara keduanya.

Pembuatan LFO bertempat di Bagian Patologi Klinik RS Dr. Hasan Sadikin, darah kelinci diambil dari pembuluh darah telinga kanan dan kiri masing-masing $2,5 \mathrm{~mL}$ dengan antikoagulan heparin dan sitrat. Teknik pembuatan untuk komponen fibrinogen menggunakan metode sentrifus dengan antikoagulan heparin, ${ }^{6}$ sedangkan komponen trombin dengan metode modifikasi Armand J Quick. ${ }^{11}$

Pembedahan cangkok konjungtiva bulbi bertempat di Laboratorium Bio Farma, terbagi atas kelompok teknik LFO dan teknik jahitan. Pengambilan bahan jaringan untuk pemeriksaan melalui ekstirpasi konjungtiva bulbi satu hari pascabedah, sampel jaringan langsung dimasukkan ke dalam reagen pengawet ribonucleic acid (RNA) dalam tempat pendingin, kemudian dikirim ke Laboratorium Sentral (Biologi Molekuler) FK 
Unpad Bandung.

Pada hari yang sama dilakukan pemeriksaan kekuatan ekspresi gen (mRNA) FN dan integrin $\alpha_{5}$ melalui tahapan isolasi RNA yang dilanjutkan dengan reverse transcriptase polymerase chain reaction (RT-PCR) dan hasilnya terlihat pada elektroforesis dalam bentuk complementary deoxyribonucleic acid (cDNA). Primer yang dipergunakan pada polymerase chain reaction (PCR) masing-masing 1 pasang untuk FN dan 1 pasang untuk integrin $\alpha_{5}$. Primer untuk FN forward 5'CTGCTGCTGCTGGCCGTCCAG 3' dan reverse 5'GTCAAAGCAAGTCTGTTCAG 3', yang akan diamplifikasi pada segmen 274 bp, sedangkan untuk integrin $\alpha_{\text {s }}$ primer yang dipergunakan forward 5'ATGGGGAGCCGGCCA GAGTC 3' untuk reverse adalah 5'CTCCTGGCT GGCTGGTATTAG 3' yang akan diamplifikasi pada segmen 120 bp. Siklus pada RT-PCR dilakukan berturut-turut 1 siklus dengan suhu $48^{\circ} \mathrm{C}$ selama 45 menit, 1 siklus suhu $94^{\circ} \mathrm{C}$ selama 2 menit dilanjutkan 40 siklus terdiri atas denaturasi dengan suhu $94{ }^{\circ} \mathrm{C}$ selama 30 detik, annealing dengan suhu $60{ }^{\circ} \mathrm{C}$ selama 1 menit, dan ekstensi dengan suhu 68 ${ }^{\circ} \mathrm{C}$ selama 7 menit. Dari hasil pengukuran kekuatan ekspresi gen yang dilakukan 1 hari pascabedah pada kelompok teknik LFO (8 mata kelinci) dan kelompok jahitan (8 mata kelinci), kemudian dilanjutkan dengan analisis data. Analisis data untuk uji hipotesis menggunakan Mann Whitney for small sample dengan uji kemaknaan $\mathrm{p}<0,05$.

Aspek etika penelitian menggunakan hewan percobaan dengan 3 prinsip (replacement, reduction, dan refinement).

\section{Hasil}

Kekuatan ekspresi gen (mRNA) FN pada teknik LFO dan teknik jahitan satu hari pascabedah bervariasi dari derajat tidak terekspresi, lemah, sedang, dan kuat.

Segmen sepanjang 274 bp pada jalur 2 sampai 6 dengan kategori sebagai berikut: pada jalur 2, 4, 5 , dan 6 terlihat segmen lebih jelas dibandingkan dengan jalur 3 dan 7 (Gambar). Hal ini berarti ekspresi gen pada jalur 2, 4, 5, dan 6 lebih kuat daripada ekspresi gen pada jalur 3 dan 7 . Dengan demikian, ekspresi gen FN satu hari pascabedah

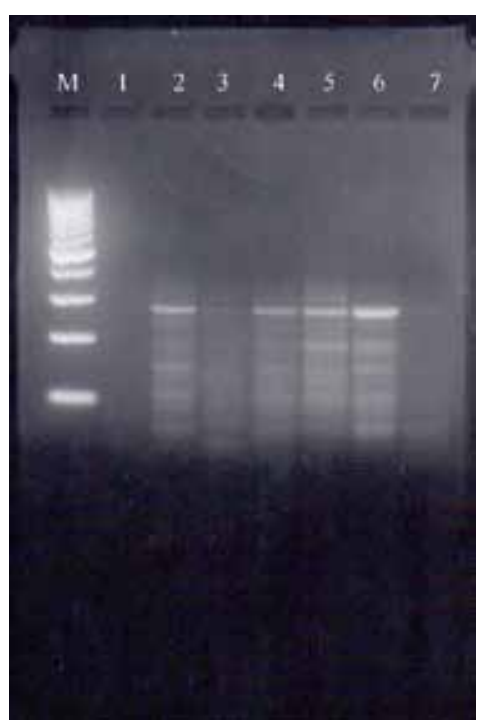

Gambar Elektroforesis Ekspresi Gen (mRNA) FN pada Segmen 274 bp

M (marker), 1 (kontrol negatif), 2 dan 4 (LFO), 3 dan 7 (jahitan), 5 dan 6 (kontrol positif)

pada teknik LFO lebih kuat dibandingkan dengan teknik jahitan.

Kekuatan ekspresi gen FN satu hari pascabedah pada teknik LFO, sebanyak 5/8 kelinci mempunyai nilai 4 atau terekspresi kuat, sebaliknya pada teknik jahitan tidak ada yang terekspresi kuat bahkan sebanyak 4/8 kelinci mempunyai nilai tidak terekspresi (Tabel 1).

Hasil uji statistik menggunakan Mann-Whitney test for small sample pada tingkat kemaknaan 5\%. Terdapat perbedaan bermakna kekuatan ekspresi gen fibronektin satu hari pascabedah tandur konjungtiva bulbi pada mata kelinci antara teknik LFO dan teknik jahitan dengan $\mathrm{p}=0,014$. Pada teknik LFO ekspresi gen mRNA FN lebih kuat dibandingkan dengan teknik jahitan (Tabel 2).

Kekuatan ekspresi gen (mRNA) integrin $\alpha_{5}$ bervariasi dari tidak terekspresi, terekspresi lemah, dan terekspresi sedang.

Teknik LFO dan teknik jahitan ternyata memperlihatkan ekspresi gen integrin $\alpha_{5}$ yang kuat. Pada teknik jahitan sebanyak $4 / 8$ kelinci mempunyai nilai 0 atau tidak terekspresi, sedangkan pada teknik

Tabel 1 Kekuatan Ekspresi Gen (mRNA) FN pada Teknik LFO dan Jahitan

\begin{tabular}{ccccc}
\hline \multirow{2}{*}{ Teknik } & \multicolumn{4}{c}{ Gradasi Ekspresi Gen FN } \\
\cline { 2 - 5 } & $\mathbf{1}$ (Tidak Terekspresi) & $\mathbf{2}$ (Lemah) & $\mathbf{3}$ (Sedang) & $\mathbf{4}$ (Kuat) \\
\hline LFO & 1 & 1 & 1 & 5 \\
Jahitan & 4 & 1 & 3 & 0 \\
\hline
\end{tabular}


Tabel 2 Analisis Kekuatan Ekspresi Gen FN antara Teknik LFO dan Jahitan Satu Hari Pascabedah

\begin{tabular}{cccc}
\hline \multicolumn{2}{c}{ Kekuatan Ekpresi Gen FN } & \multicolumn{2}{c}{$\begin{array}{c}\text { Uji Mann- } \\
\text { Whitney }\end{array}$} \\
\hline $\begin{array}{c}\text { Teknik LFO } \\
(\mathbf{n}=\mathbf{8})\end{array}$ & $\begin{array}{c}\text { Teknik Jahitan } \\
(\mathbf{n = 8})\end{array}$ & Wx & $\mathbf{p}$ \\
\hline 4 & 3 & 47 & 0,014 \\
4 & 1 & & \\
4 & 3 & & \\
4 & 3 & & \\
4 & 1 & & \\
3 & 1 & \\
2 & 1 & \\
1 & 2 & \\
\hline Keterangan: Wx: jumlah skor jahitan \\
Kelompok teknik LFO dan jahitan pada kelinci \\
berbeda (independent) \\
Nilai gradasi ekspresi gen 4 (kuat), 3 (sedang), \\
2 (lemah), 1 (tidak terekspresi)
\end{tabular}

LFO sebanyak 4/8 kelinci terekspresi sedang (Tabel $3)$.

Hasil uji statistik menggunakan Mann-Whitney for small sample test pada tingkat kemaknaan $5 \%$. Ternyata tidak terdapat perbedaan bermakna kekuatan ekspresi gen integrin $\alpha_{5}$ satu hari pascabedah tandur konjungtiva bulbi pada mata kelinci antara teknik LFO dan teknik jahitan dengan $\mathrm{p}=0,253$ (Tabel 4). Teknik LFO mempunyai kecenderungan terekspresi sedang, sedangkan pada teknik jahitan tidak terekspresi.

\section{Pembahasan}

Penelitian uji eksperimental hewan secara bermakna teknik LFO lebih baik dibandingkan dengan teknik jahitan, pada teknik LFO lama operasi lebih singkat disertai penempelan jaringan dan penyembuhan luka pascabedah lebih cepat. ${ }^{9}$

Untuk penempelan jaringan cangkok dan penyembuhan luka diperlukan interaksi $\mathrm{FN}$ dan integrin $\alpha 5 \beta 1$ yang akan mengaktivasi alur persinyalan di dalam sel, sehingga jaringan cangkok yang ditempelkan pada dasarnya tetap survive. ${ }^{9}$

Memahami mekanisme kerja LFO pada proses penempelan jaringan dan penyembuhan luka dapat dilakukan secara biologi molekular melalui pemeriksaan ekspresi gen FN dan integrin yang secara dini dapat dideteksi dari peningkatan ekspresi gen (mRNA) kedua protein tersebut.

Tabel 3 Kekuatan Ekspresi Gen (mRNA) Integrin $\alpha_{5}$ pada Teknik LFO dan Jahitan

\begin{tabular}{lcccc}
\hline \multirow{2}{*}{ Teknik } & \multicolumn{4}{c}{ Gradasi Ekspresi Gen Integrin $\boldsymbol{\alpha}_{5}$} \\
\cline { 2 - 5 } & $\mathbf{1}$ (Tidak Terekspresi) & 2 (Lemah) & 3 (Sedang) & 4 (Kuat) \\
\hline LFO & 3 & 1 & 4 & 0 \\
Jahitan & 4 & 2 & 2 & 0 \\
\hline
\end{tabular}

Tabel 4 Analisis Kekuatan Ekspresi Gen (mRNA) Integrin $\alpha_{5}$ antara Teknik LFO dan Jahitan Satu Hari Pascabedah

\begin{tabular}{cccc}
\hline \multicolumn{2}{c}{$\begin{array}{c}\text { Kekuatan Ekpresi Gen } \\
\text { Integrin } \boldsymbol{\alpha}_{\boldsymbol{5}}\end{array}$} & \multicolumn{2}{c}{$\begin{array}{c}\text { Uji Mann- } \\
\text { Whitney }\end{array}$} \\
\hline $\begin{array}{c}\text { Teknik LFO } \\
(\mathbf{n}=8)\end{array}$ & $\begin{array}{c}\text { Teknik Jahitan } \\
(\mathbf{n}=\mathbf{8})\end{array}$ & $\mathbf{W x}$ & $\mathbf{p}$ \\
\hline 1 & 2 & 61 & 0,253 \\
3 & 3 & & \\
2 & 1 & & \\
3 & 2 & & \\
3 & 1 & & \\
3 & 3 & & \\
1 & 1 & & \\
1 & 1 & & \\
\hline
\end{tabular}

Keterangan: Wx: jumlah skor jahitan

Kelompok teknik LFO dan jahitan pada kelinci berbeda (independent)

Nilai gradasi ekspresi gen 4 (kuat), 3 (sedang), 2 (lemah), 1 (tidak terekspresi)
Gradasi ekspresi gen (mRNA) FN pada teknik LFO berbeda dengan teknik jahitan (Tabel 1). Pada teknik LFO ekspresi gen (mRNA) FN sebagian besar (5/8) kelinci terekspresi kuat, sedangkan pada teknik jahitan tidak ada yang terekspresi kuat. Berdasarkan analisis statistik terdapat perbedaan kekuatan ekspresi gen mRNA antara teknik LFO dan teknik jahitan (Tabel 2).

Pemberian LFO pada pembedahan akan memintas tahap akhir pembentukan fibrin yang dalam keadaan alami harus melalui faktor intrinsik dan ekstrinsik. ${ }^{7,12}$ Dengan tersedianya fibrin dari LFO dalam jumlah yang cukup dan dalam waktu yang cepat akan merupakan stimulan atau memicu fibroblas untuk berproliferasi dan bermigrasi ke tempat luka. Di tempat tersebut fibroblas akan mensintesis matriks baru, antara lain FN yang merupakan glikoprotein adhesif yang banyak berperan untuk memperbaiki integritas jaringan. ${ }^{6}$

Pada penelitian secara praklinik dan histologis 
penggunaan LFO pada tandur konjungtiva bulbi menunjukkan celah luka dan attachment jaringan lebih baik secara kualitas dan kuantitas, ${ }^{6}$ ditunjang dengan ekspresi FN yang kuat pada hasil PCR memperkuat hipotesis bahwa LFO tidak hanya menempelkan jaring cangkok secara mekanis, tetapi juga bersifat biostimulator mempercepat penyembuhan luka. Sebaliknya, teknik jahitan pada transplantasi jaringan akan merupakan trauma (injury) tambahan pada sel, pembuluh darah, dan matriks ekstraselular. Terdapatnya benang merupakan benda asing akan menimbulkan reaksi inflamasi lebih besar dan lebih lama, sehingga penyembuhan jaringan terjadi lebih lambat. ${ }^{12}$

Reseptor permukaan sel juga menerima sinyal lain dari ekstraselular, dapat berupa perubahan mikroenviromental yang berbentuk fisik, kimia, dan biologis yang akan mempengaruhi regulasi faktor transkripsi yang bersifat stimulasi atau inhibisi terhadap ekspresi gen. ${ }^{13}$

Pada pemeriksaan ekspresi gen (mRNA) integrin $\alpha_{5}$ satu hari pascabedah tandur konjungtiva bulbi mata kelinci, tidak terdapat perbedaan antara kelompok teknik LFO dan teknik jahitan (Tabel 4). Ekspresi gen (mRNA) integrin $\alpha_{5}$ pada kedua kelompok tidak ada yang terekspresi kuat, namun terdapat kecenderungan perbedaan ekspresi pada kedua kelompok dengan gradasi pada teknik LFO terekspresi lebih kuat dibandingkan dengan teknik jahitan (Tabel 3).

Pada ekspresi integrin $\alpha_{5}$ tidak pernah terekspresi kuat, hal ini sesuai dengan konsep sentral fungsi integrin yang akan berikatan dengan FN selalu dalam pergeseran aktif dan tidak aktif bergantung pada perubahan domein ekstraselular dari integrin. Transisi kedua keadaan tersebut secara dinamis diregulasi oleh sel melalui energi dari kejadian yang melibatkan bagian sitoplasma integrin. Pada penempelan sel, integrin umumnya dalam keadaan aktif dan kemungkinan menjadi tidak aktif sewaktu migrasi dan mitosis. ${ }^{9}$

Pada transplantasi jaringan akan terjadi trauma pada sel serta berbagai jaringan, dapat bersifat fisik maupun kimia bergantung pada teknik operasi yang dilakukan dan akan berakibat pada penyembuhan jaringan. Manipulasi yang berlebih pada jahitan akan menimbulkan akumulasi kerusakan DNA yang akan memicu ekspresi gen tertentu dan menimbulkan kematian

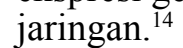

Gradasi ekspresi gen (mRNA) integrin $\alpha_{5}$ satu hari pascabedah tandur konjungtiva bulbi lebih kuat pada teknik LFO dibandingkan dengan teknik jahitan, tetapi secara analisis statistik tidak terdapat perbedaan yang bermakna (Tabel 3).

Belum terdapatnya perbedaan bermakna ekspresi gen (mRNA) integrin $\alpha_{5}$ pada kedua teknik tersebut karena terdapatnya 3 faktor penting yang menghambat ekspresi gen (mRNA) integrin $\alpha_{5}$ satu hari pascabedah, yaitu terganggunya interaksi sel ekstraselular yang menginhibisi aktivasi persinyalan intraselular, ${ }^{9}$ kadar ion $\mathrm{Ca}^{2+}$ yang tinggi pada jaringan yang mengalami kerusakan, ${ }^{13}$ dan diperlukan waktu sekitar 22 jam untuk pembentukan sel baru. ${ }^{13}$

Berdasarkan hasil penelitian ini, pada pemeriksaan satu hari pascabedah cangkok konjungtiva bulbi, ekspresi gen (mRNA) FN lebih kuat pada teknik LFO dibandingkan dengan teknik jahitan, sedangkan ekspresi gen (mRNA) integrin $\alpha_{5}$ gradasi pada teknik LFO lebih kuat dibandingkan dengan teknik jahitan, tetapi secara statistik tidak terdapat perbedaan bermakna.

Aplikasi teknik LFO pada tandur konjungtiva bulbi mempunyai pengaruh kuat pada ekspresi gen (mRNA) FN yang berperan dalam adhesi jaringan dan akan mempercepat penyembuhan luka, menunjang penelitian terdahulu pada tingkat praklinis serta histologis. Dampak klinis penelitian ini dapat dijadikan dasar ilmiah untuk penelitian lanjutan uji klinis penggunaan teknik LFO pada cangkok konjungtiva bulbi setelah eksisi bedah pterigium sebagai alternatif pengganti teknik jahitan.

Penelitian ini mendapat dana yang bersumber dari dana PHB yang dikelola oleh Dikti Tahun Anggaran 2009.

\section{Daftar Pustaka}

1. Ali BMS, Khokhar AR, Ali MA, Khan MS, Ahmed I. Conjuctival autograft for primary and recurrent pterygium. Pakistan J Surg. 2008;24:173-6.

2. Midha A, Srivastava S, Sharma M, Jain P. Fibrin glue-A safe, effective, patient and surgeon friendly technique for attaching limbal conjunctival autografts in comparison to conventional suturing-a prospective technique. AIOC. 2008. [diunduh 20 Maret 2009]. Tersedia dari: http://www.aios.org/ proceed08/papers/EXT/Ext6.pdf.

3. Kaufman HE, Insler MS, Ibrahim-Elzembly HA, Kaufman SC. Human fibrin tissue adhesives for suturless lamellar keratoplasty and scleral patch adhesion. Ophthalmology. 2003;110:2168-72.

4. Hannush SB. Pterygium, tissue glue, and the future of wound closure. Dalam: Mascai MS, penyunting. Ophthalmic microsurgical suturing technique. Heidelberg: Springer; 2007. hlm. 135-9.

5. Koranji G, Seregard S, Kopp ED. Cut and paste: a no suture, small incision approach 
to pterygium surgery. $\mathrm{Br} \mathrm{J}$ Ophthalmol. 2004;88:911-4.

6. Enus S, Dalimoenthoe NZ, Kartiwa A. Teknik lem fibrin otologus pada cangkok konjungtiva bulbi mata kelinci. MKB. 2009;41(4):169-73.

7. Uy HS, Reyes JM, Flores JD, Lim-BongSiong R. Comparison of fibrin glue and sutures for attaching conjungtival autografts after pterygium excision. Ophthalmology. 2005;112:667-71.

8. Spotnitz WD. Commercial fibrin sealants in surgical care. Am J Surg. 2001;182:8S-14.

9. Clark K, Pankov R, Travis MA, Askari JA, Mould AP, Craig SECS. A specific $\alpha_{5} \beta_{1}$ integrin conformation promotes directional integrin translocation and fibronectin matrix formation. J Cell Sci. 2005;118:291-300.

10. The Association for Research in Vision of Ophthalmology. Statement for the use of animals in ophthalmic and visual research (ARVO) [diunduh 7 Oktober 2004]. Tersedia dari: http://www.arvo.org?aboutARVO/ animals.asp.

11. Saxena S, Jain P, Shukla J. Preparation of two component fibrin glue and its clinical evaluation in skin graft and flaps. Indian $\mathbf{J}$ Plast Surg. 2003;36:14-7.

12. Man D, Plosker K, Winland-Brown JE. The use of autologous platelet-rich plasma (platelet gen) and autologous platelet-poor plasma (fibrin glue) in cosmetic surgery. Plast Reconstr Surg. 2001;107:229-37.

13. Pollard TD, Earnshaw WC. Cell biology. Edisi ke-2. Philadelphia: Saunders; 2008.

14. Shahib MN. Lecture notes on medical molecular biology. Genetic information. Bandung: Departement of Biochemistry Faculty of Medicine Padjadjaran University; 2002. 